\title{
Prediction and prevention of geological hazards
}

\begin{abstract}
Japan has experienced many major natural disasters caused by earthquakes, volcanic eruptions, landslides, floods, and other hazards, because it is located on very active island-arc systems. This has encouraged the study of natural disasters. Earthquake prediction started as a national project in 1966, and it is now in its sixth 5-year program. The earthquake observation network has been expanded, and data-analysis methods have been greatly modernized. The prediction of volcanic eruptions has also proceeded as a national project and is in its fourth 5-year program. Predictions for each volcano have been successful owing to a variety of monitoring methods selected on the basis of differences in magmatic character, Landslide disaster has been greatly mitigated through developments in the prediction of their site, type, magnitude, and occurrence time, in addition to the building of extensive control works. Recently, time prediction of landsliding has become highly reliable through the monitoring of ground movement.
\end{abstract}

\section{Earthquakes}

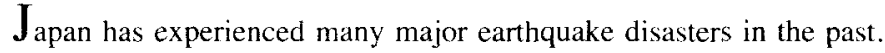
In 1923, 140,000 people were killed by the Kanto great earthquake that occurred in the Tokyo metropolitan area. Because it is located in the Circum-Pacific seismic belt, Japan is one of the most earthquakeprone countries in the world. This has led to great interest in earthquake prediction, ever since seismological studies were begun in Japan a century ago.

Earthquakes occur when stress within the Earth's crust reaches a limit, and a sudden fracture (the sudden slip of a fault) occurs in part of the crust. In general, brittle materials fracture suddenly, and it is difficult to predict this fracture accurately. Fortunately, ruptures of the crust do not happen without warning, in most cases. As stress on the crust increases, crustal changes proceed by degree, and various phenomena occur immediately before the principal rupture. The crust is mechanically very complex (for example, in heterogeneous strength distribution), and ground water exists in the pores in the rocks of the crust. These properties of the crust are useful for earthquake prediction. A wide variety of precursory phenomena have been observed, including anomalous crustal movements; anomalous seismic activity; and changes in the level, temperature, and chemical components of ground water, in some cases. If researchers focus on these changes and are able to adequately trace them, long-term and short-term predictions are possible.

In 1965, earthquake prediction was undertaken as a national project, and it is now in its sixth 5-year program. During this period, the expansion of the earthquake observation network and the modernization of data-analysis methods have been striking. Other methods for observing crustal movements, geomagnetism, and groundwater have also been improved. In 1969. the Coordinating Committee for Earthquake Prediction was established to gather and examine the data on a regular basis and to investigate long-term prediction.

The possibility of a large earthquake in the Tokai region of central Honshu Island was pointed out, in 1969. It became a major social issue in 1976. because a disaster of serious consequence was (and still is) expected, if such an earthquake were to occur. In 1978. the Large-Scale Earthquake Countermeasures Act was enacted. Under this law. the prime minister is to issue a public warning, and government and private organizations are to respond immediately by adopting effective procedures. Observation stations are densely located from the Tokai region to the southern Kanto district, and currently 133 data sets are telemetered to Japan Meteorological Agency in Tokyo where they are monitored 24 hours a day (fig. 1). If any anomalies are discovered, the Earthquake Assessment Committee is to meet immediately and assess the data. This is an important national experiment aimed at minimizing the disaster by predicting the earthquake, and it is the first step toward practical earthquake prediction.

Several major earthquakes have occurred since the start of the earthquake prediction program. Although there have been successful examples of prediction on the basis of seismic gap theory, as for the 1973 Nemuro-Hanto-oki earthquake, there have been no cases in which all three elements of earthquake prediction-place, magnitude, and time-have been successfully forecast. However, reliable data on precursory phenomena are being steadily accumulated, and several cases suggest the feasibility of earthquake prediction.

As an example, the case of the 1983 Sea of Japan earthquake of M 7.7 is explained in figure 2. The Sea of Japan is far less active than the Pacific side of Japan. This earthquake was the largest earthquake on the Sea of Japan side, and its focal region covered an area $120 \mathrm{~km}$ long and $40 \mathrm{~km}$ wide, extending from south to north. As shown in figure 2 , various precursory phenomena occurred prior to the earthquake: (i) foreshocks very near the epicenter of the main shock; (ii) seismic quiescence in a wide area including the focal region of the earthquake (the seismic gap of the second kind); (iii) active earthquake swarms in the surrounding region (1-5 in fig. 2 ); (iv) volcanic eruptions in the surrounding region ( $A$ and $B$ in fig. 2 ); (v) ground uplifts along the western coast ( $a$ and $b$ in fig. 2) observed by tiltmeters, tide gages, and leveling surveys. Though the Sea of Japan earthquake occurred out to sea, quite distant from the observation network on land, the various kinds of precursory phenomena were observed. This suggests that if careful and appropriate monitoring is carried out, it will be possible to forecast, to a certain extent, a large earthquake of this magnitude.

\section{Volcanic eruptions}

In Japan, there are many active volcanoes. Prediction of volcanic eruptions is also a national project, which is now in its fourth 5-year program. The process of prediction of volcanic eruptions is different for different types of magma. Eruptions of the dacite-type Usu 


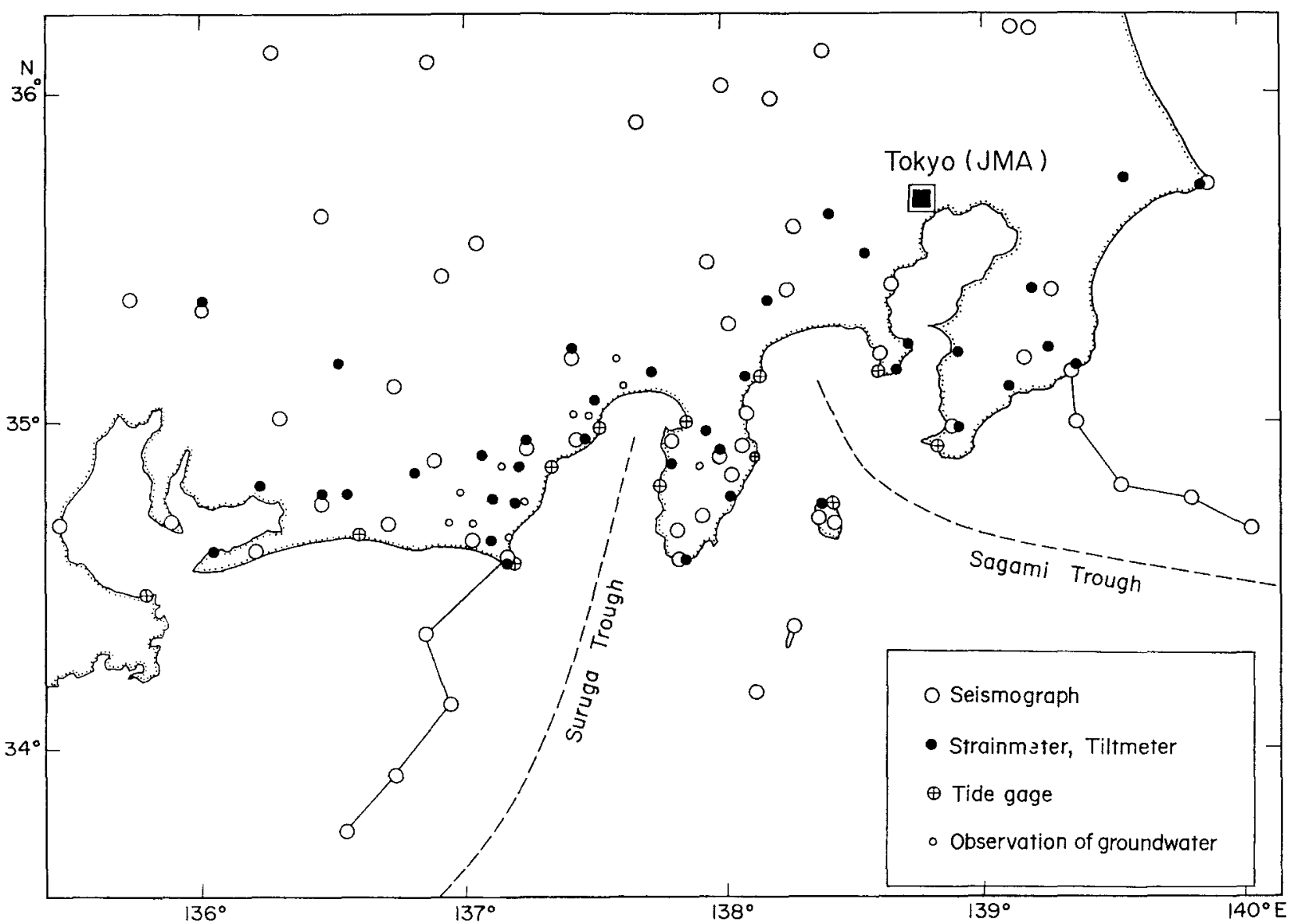

Figure 1.-Distribution of the observation stations for full-time monitoring of precursory phenomena of earthquakes in the Tokai region. Observed data are transmitted to Japan Meteorological Agency in Tokyo.

volcano. which started from the August 1977, were preceded by the occurrence of a number of strong earthquakes. In the case of the anclesite-type Sakurazima volcano, recent successive eruptions have been predicted successfully by careful observations of crustal deformation in accordance with the inflation-deflation model. Prior to the 1985 eruption of the basalt-type Izu-Oshima volcano, remarkably apparent electrical resistivity changes beneath the crater region were observed. In this case, a long-term change in geomagnetism was also observed before the eruption. In many cases, the commencement of strong volcanic eruption has been predicted successfully, but it was more difficult to forecast a future activity after the beginning of volcanic eruption. and this is also an important problem.

As a recent intereving example. the 1989 fto-oki submarine volcanic eruption is explained in figure 3. Since 1978, very active earthquake swarms occurred successively off the east coast of the Izu Peninsula of central Honshu. The hypothesis that these earthquake swarms were caused by magma intrusion has been proposed by a number of investigators. Figure 3 shows that the focal regions of earthquake swarms since 1988 migrated from the southeast to the northwest and from deep to shallow. The focal depth of the last earthquake swarm of July 1989. Was extremely shallow, and the submarine volcanic eruption occurred at the center of the focal region of the earthquake swarm just after the peak of the swarm activity. This is an example of successful long-term forecasting of the generation of a new volcano.

\section{Landslide hazards}

$J_{\text {apan is also one of the most typical examples of landslide prone }}$ areas in the world. This, too, is related to the geological situation of the Japanese islands being island ares along the plate boundaries, where the Pacific and Philippine plates are subducting under the Eurasian plate. As a result of this neotectonic activity, the Japanese islands consist of Quatemary volcanic rocks, thick but weakly consolidated Neogene deposits and submarine volcanic rocks, older sedimentary rocks, and crystalline rocks. These rocks have been severely defornied and weathered or hydrothermally altered by the tectonic activity, volcanism, and the humid climate of the islands. The 1,000-3,000-m mountains, which were constructed by the reotectonic activity, and the location of the islands between the Eurasian continent and the Pacific Ocean create a subtropical moonsoon climate that results in a large amount of precipitation--more than 1500 $\mathrm{mm} / \mathrm{yr}$. This contributes to the formation of thick weathering crusts and colluvial deposits on slopes. Landsliding is the main erosion style in specific zones, owing to the nature of the geological materials and the triggering agents of precipitation. strong earthquake motion, and volcanic activity. Landslides or mass movements can be classified into three types: creep slide, rapid slide, and debris flow (Japan Landslide Society, 1988). 5,539 landslides were designated for control works by the Ministry of Construction and the Ministry of 


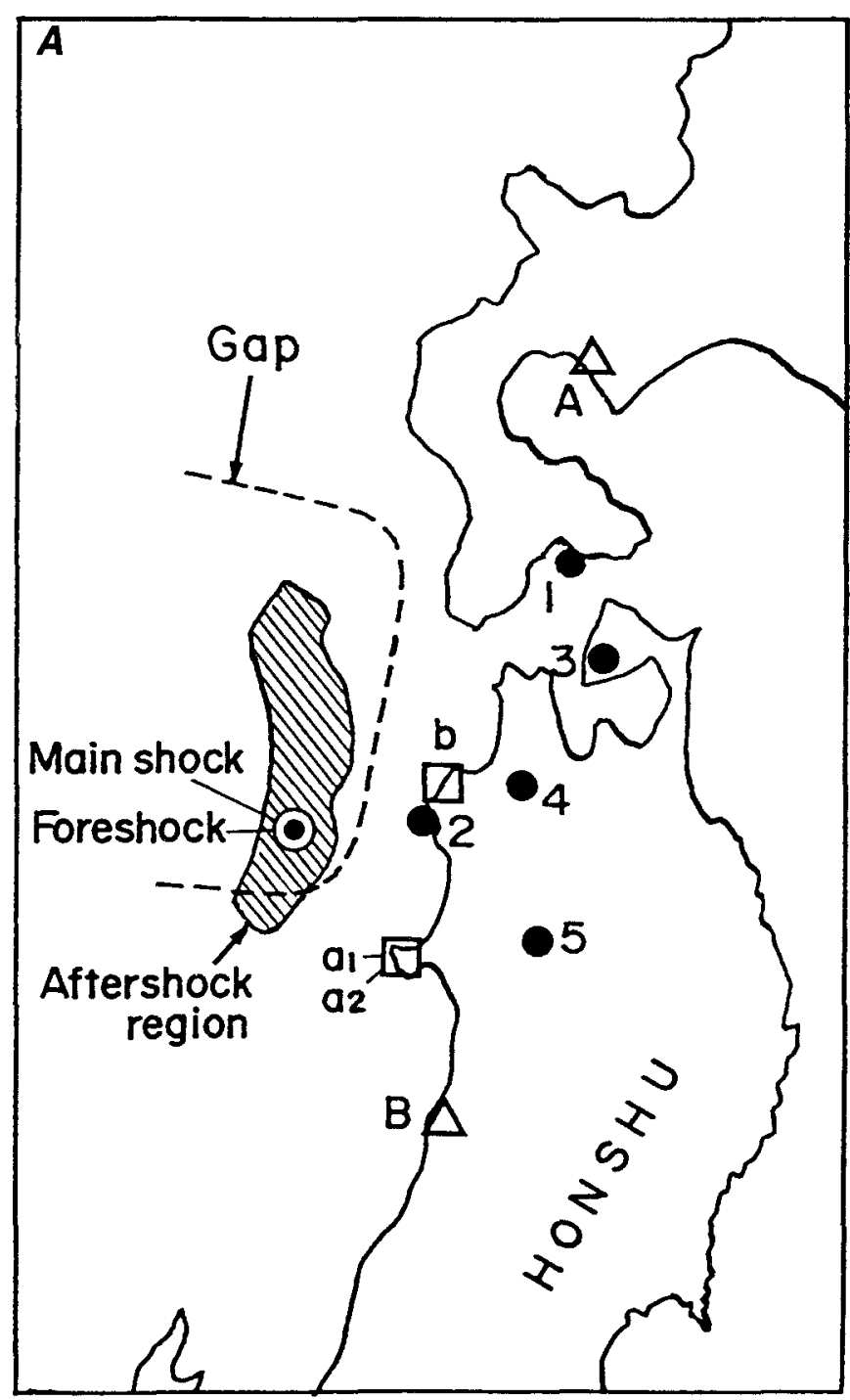

Agriculture, Forestry, and Fisheries. This designation of landslides is based on the Landslide Prevention Law, enacted in 1958. The landslides are distributed throughout the country, but most of them are concentrated in specific belts (fig. 4).

Japan is divided into 15 geological zones on the basis of landslide types and their hazard characteristics (Oyagi, 1989). These geological zones are: 1, the zone of Granites and gneisses; 2, Late Mesozoic to Paleogene terrestrial volcanics; 3, serpentine and associated basic rocks; 4, Paleozoic to Middle Mesozoic sedimentary rocks of crystalline schist facies; 5 , those of nonmetamorphosed facies; 6, Late Mesozoic turbidite sedimentary rocks; 7, Late Mesozoic to Paleogene Tertiary flysh type rocks; 8 , Paleogene to Early Neogene nonmarine and neritic sediments; 9, Miocene submarine volcanic rocks; 10, Miocene to Pliocene marine clastic sediments; 11, Late Miocene to Early Pleistocene terrestrial volcanic rocks; 12 , Quaternary terrestrial and neritic sediments; 13, Quaternary pyroclastic rocks and sediments; 14, Quaternary volcanic rocks composing volcanic edifice; and 15, Late Pleistocene and Holocene sediments

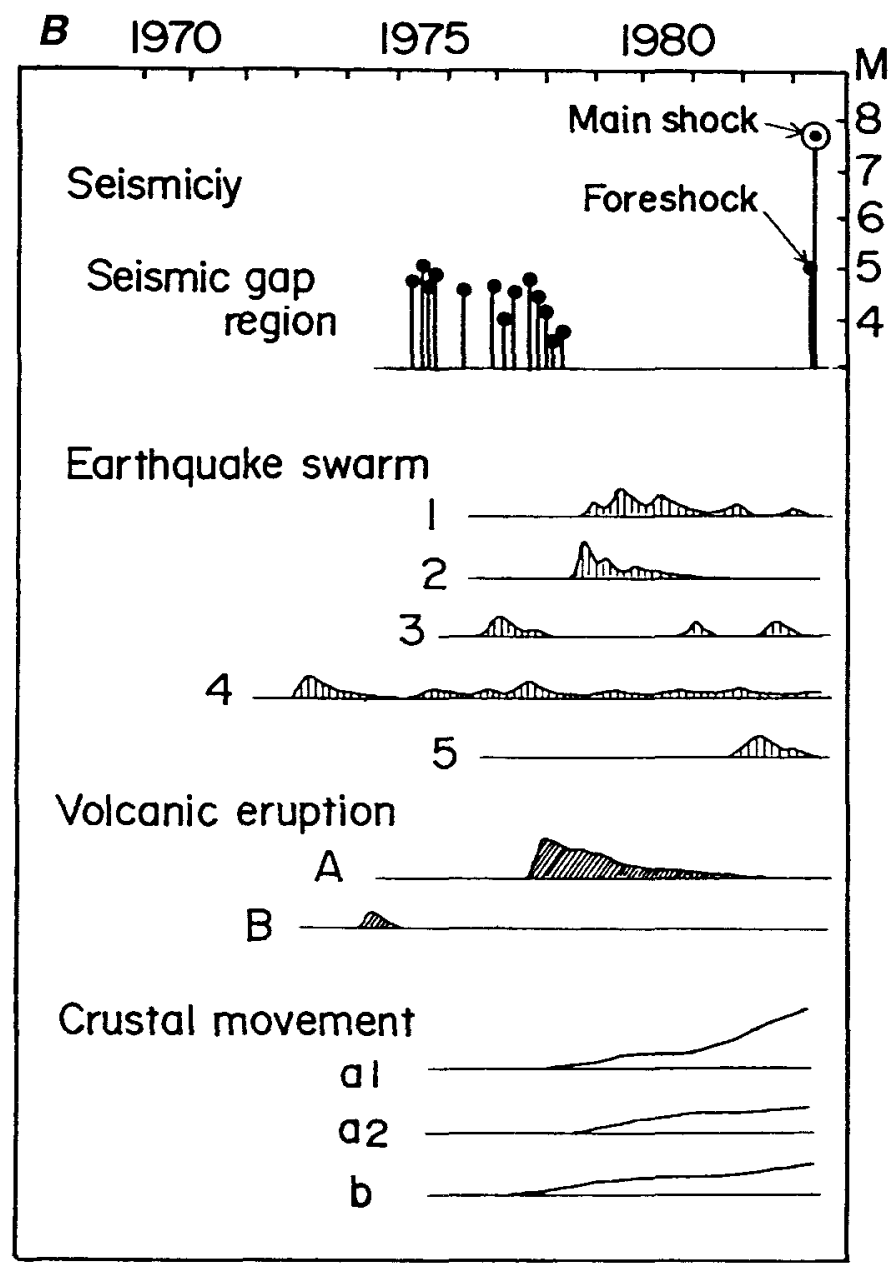

Figure 2.-A, locations of the main shock, foreshocks, and aftershocks of the Sea of Japan earthquake and other observed precursory phenomena; $B$, temporal variation of various phenomena.
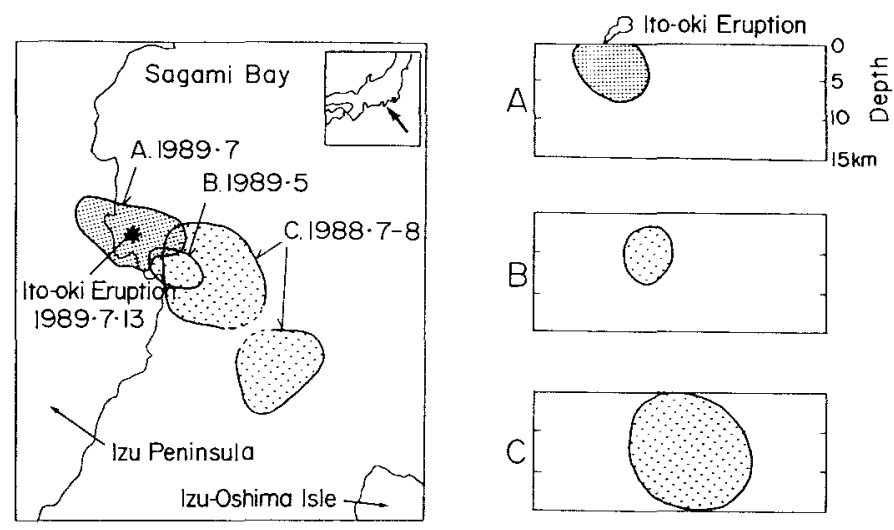

Figure 3.-1989 Ito-oki submarine eruption and successive earthquake swarms. Left, horizontal distribution; right, vertical distribution. 
filling valleys. The most prominent zones of hazards of the creepslide type landslides are those of the Miocene submarine volcanic rocks, zone 9, and of the Miocene to Pliocene marine clastic sediments, zone 10 . In most of these two zones, creep slide landslides sites can usually be predicted by geomorphological and geological interpretation of aerial photographs. Landslide geomorphological mapping has been almost completed in the northern part of Japan. the Hokkaido and Tohoku districts. Landslides of rapid slide type occur most typically in the zone of granites and gneisses, zone 1, as well as in Palaeozoic and Mesozoic deposits, zone 3. These landslides often turn into or cause debris flows. The method for predicting sites for those landslides caused by heavy rainfall has been developed by the stability-analysis calculation in each cell, by introducing data on of groundwater concentration during rainfall, soil shear strength, root system strength, and slope structure.

The movement of important landslides is monitored by such instruments as extensometers, inclinometers, multilayer displacement-meters, pore-pressure gages, rain gages, and laser distance measurement. The time of destructive failure of landslide slopes can be predicted by the displacement-time relationships and the reciprocal velocity-time relationship on the basis of creep theory. The final failure time of such a landslide as the Jizukiyama landslide in Nagano City at 5 pm on July 26, 1985, should be predicted by those relationships about 2 hours before its occurrence.

Three field trips of the IGC 29, B01, B02, and C16, will show several types of landslides and countermeasures to mitigate landslide hazards in several geological zones, especially the zones 1 , $9,10,14$, and 15 .

The trip B01 will present the Kamenose landslide, which belongs to zone $9,50 \mathrm{~km}$ south of Kyoto, one of the most famous landslides in Japan (fig. 5). The landslide made two large movements during the 60 years since 1930. In 1931-1932, a landslide mass $1 \mathrm{~km}$ wide, $1 \mathrm{~km}$ long, and $60 \mathrm{~m}$ deep moved $53 \mathrm{~m}$ along a slide surface and lifted up the floor of the Yamato River $36 \mathrm{~m}$ and the opposite slope of the river $32 \mathrm{~m}$. The toe of the landslide blocked the river and caused inundation in the southwestern part of the Nara basin, the ancient cultural area. It destroyed a section of railway and of a national highway. In 1967, the landslide again moved $26 \mathrm{~m}$ along the slide surface and lifted up the surface of the river floor and the highway on the opposite slope $1.4 \mathrm{~m}$. The Kamenose landslide area is underlain by volcanic rocks with intercalated clastic rocks. The slide surface of the landslide is developed in a highly altered part of
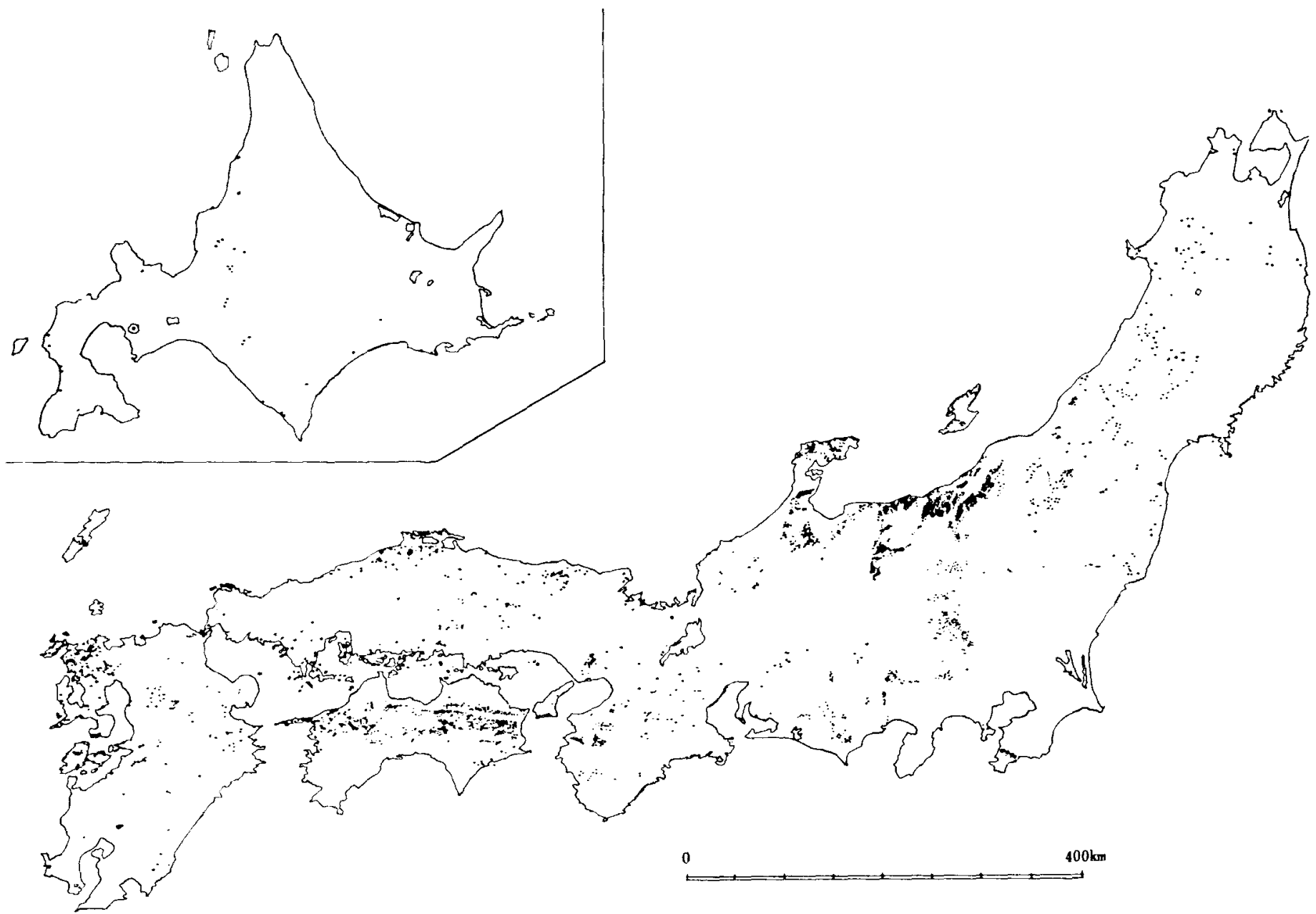

Figure 4.-Distribution of landslides designated for control works by Japanese Government. 


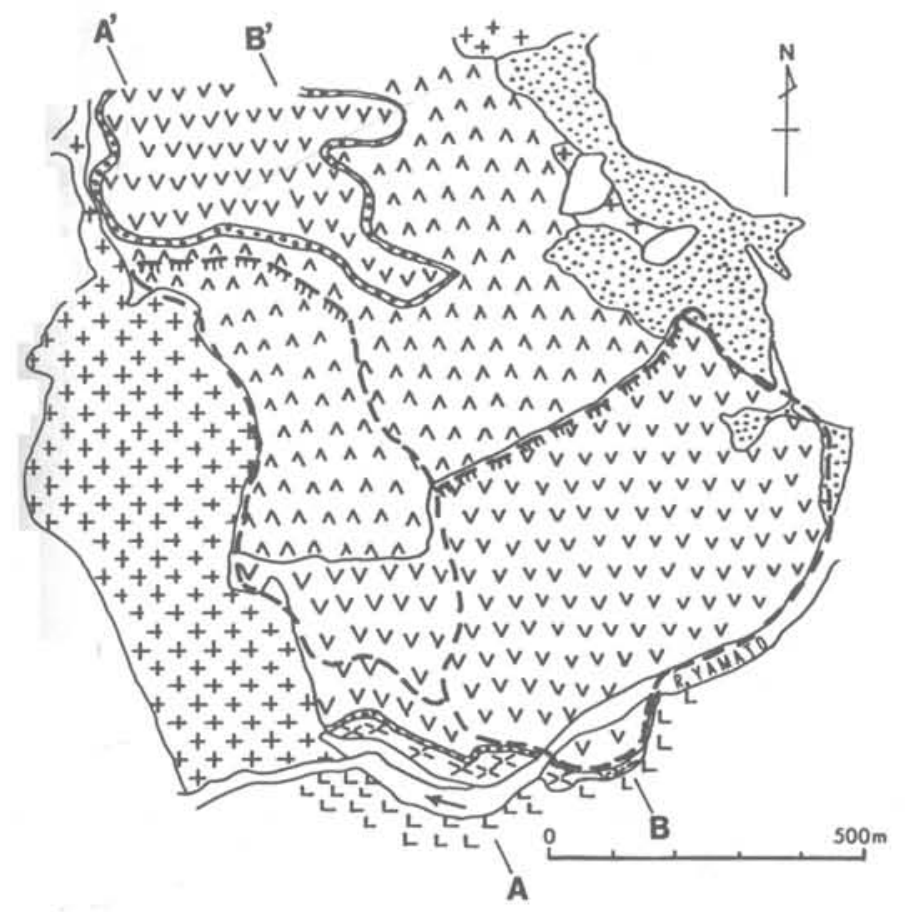

A
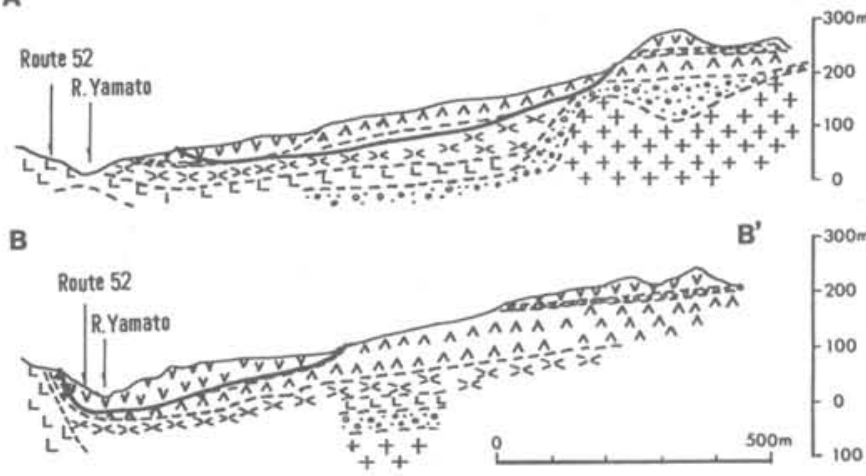

$\because 0$ $\sin ^{\wedge} A$ ㅁํㅇ

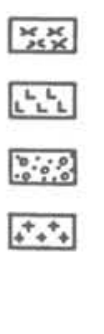

Tuff, tuffbreccia, sandstone, conglomerate (Harakawe Formation)

\section{Myojin lava}

Conglomerate

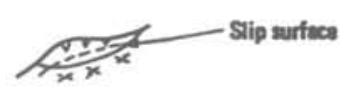

Ryoke granitic rocks

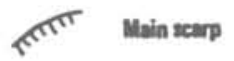

Figure 5.-Geological map and longitudinal section of Kamenose landslide. Osaka Prefecture.

the volcanic rocks. Very extensive control works for stabilization of the landslide have been built by the Ministry of Construction over the past forty years because of the importance of land conservation and traffic flow in the landslide area. Visitors will clearly recognize the geological and geomorphological situation and the engineering practices to mitigate the landslide hazards through seeing the showroom of the landslide and taking an outdoor walk in the landslide area. They will understand how to design and construct such important control works as cast-in-place reinforced concrete pilings, systematically combined drainage works of tunnels and wells, mass removal works, and so on.

The field trip B02 will be to Rukko Mountain, which is composed of granitic rocks that are highly fractured and deeply weathered and belongs to zone 1 . Shallow, rapid landslides and debris flows were induced here by heavy rainfall in 1938, 1961, and 1967. These landslides caused severe disasters in cities developed on the alluvial fans surrounding the mountain. A series of check dams and channels has been extensively constructed along each stream on the mountain for erosion control and mitigation of landslide hazards.

Postsymposium excursion C16 will show recent and famous landslides in Niigata and Nagano Prefectures - the main part of zone 10 , which is also characterized by creep slide type landslides in Japan. This zone is underlain by upper Miocene clastic sediments that are rich in mudstone. Landslides in the area are thin $(5 \mathrm{~m})$ to thick $(40 \mathrm{~m})$ and have a length of $100-1000 \mathrm{~m}$. They usually move very slowly (several centimeters per year, during snow melt season), but sometimes they slide rapidly as a result of large increases of pore pressure along the sliding surface that are caused by a large amount of precipitation or snow melt. Many of these landslides are thought to be the reactivation of ancient, large-scale landslides that moved in the late Pleistocene on the basis of carbon fourteen ages of several wood samples from the landslide deposits. The Jizukiyama landslide is an example of the reactivation of an ancient landslide (fig. 6). Recent control works for such landslides have greatly mitigated human casualties, but they still cause great economic loss, particularly in paddy fields on landslide slopes. An interesting aspect of the slopes is the stepped array of paddy fields and the very narrow interval. Visitors will see how the landslide slopes relate to culture and agriculture. This field trip, C16, also involves visiting areas of debris-flow disasters in granitic rocks (zone 1) and the Quaternary

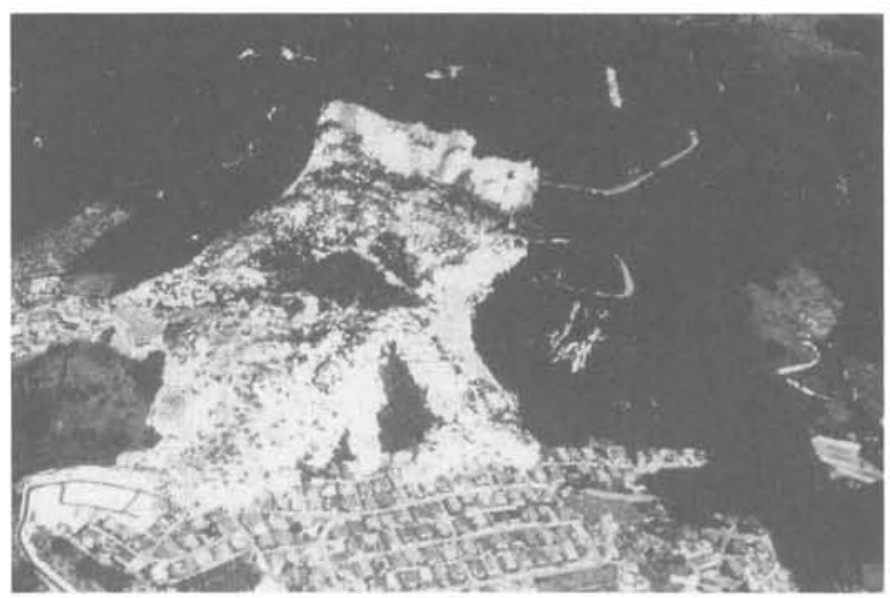

Figure 6.-Oblique aerial photograph of Jizukiyama landslide, Nagano City, 55 houses and 1 hospital were buried and 26 aged persons were killed by the landslide debris. 
volcanoes (zone 14), and sites of liquefaction caused by the 1964 Niigata earthquake in alluvial deposits (zone 15).

\section{References}

Erosion Control Society Japan, 1985, Erosion control in Japan: Japan Sabo Association, $67 \mathrm{p}$.

Japan Landslide Society, 1988, Landslides in Japan, Japan Landslide Society, Tokyo, $54 \mathrm{p}$.

Mogi, K., 1985, Earthquake prediction: Tokyo, New York, Academic Press, $355 \mathrm{p}$.

Okada, H., 1986, Volcanic surveillance and prediction of volcanic eruptions: Bulletin of the Volcanological Society of Japan, v. 30, p. S301-S305.

Oyagi, N., 1989, Geological and economic extent of landslides in Japan and Korea, in Brabb, E.E., and Harrod, B.L., eds., LandslidesExtent and Economic Significance: Rotterdam/Brookfield, A.A. Balkema, p. 289-302.

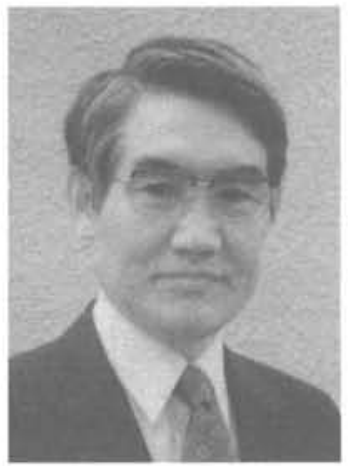

Dr. Kiyoo Mogi was Professor of the Earthquake Research Institute, University of Tokyo from 1969 to 1990. and Director of the Institute from 1988 to 1990. Born in Yamagata, Japan, Dr. Mogi graduated from the University of Tokyo with a doctoral degree in seismology. He is Professor Emeritus of the University of Tokyo. Professor of Nihon University, fellow of $A G U$, Chairman of the Coordinating Committee for Earthquake Prediction in Japan, Chairman of the Earthquake Assessment Committee for the Tokai earthquake.

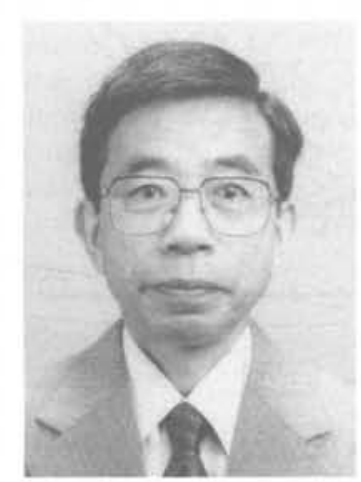

Dr. Norio Oyagi is Director of the Disaster Prevention Research Division of the National Research Institute for Earth Science and Disaster Prevention. Born in Nagasaki, Japan, he graduated from Hiroshima University with a doctoral degree in petrology. He has studied landslides from the geological and the geomorphological point of view from 1964. $\mathrm{He}$ is Chairman of the International Committee of the Japan Landslide Society and was President of the Japanese Geomorphological Union 'from 1989 to 1991. 